\title{
Vladislav Suvák: Kynizmus grécky a moderný $I^{2}$
}

Prešov, Vydavatel'stvo Prešovskej univerzity 2014, 123 s.

V roku 2014 vyšla vd'aka projektu a dotácie Agentúry na podporu výskumu a vývoja knižná publikácia v podobe vysokoškolskej učebnice s názvom Kynizmus grécky a moderný I. Autor Vladislav Suvák je jedným zo slovenských korifejov kynickej filozofie, ktorú spolu s d’alšími vedecko-pedagogickými spolupracovníkmi šíri a buduje na slovenskej akademickej pôde. Obsahovo predstavuje učebnicový text rozšírenie a doplnenie staršej autorovej štúdie Kynizmus: etika bez morálky (In Suvák 2007) o primárne texty, zlomky ku kynickej filozofii. Uvedená učebnica vznikla zároveň v spojitosti s vysokoškolským kurzom rovnakého názvu, ktorý bol určený pre študentov odboru filozofie a etiky na Filozofickej fakulty Prešovskej univerzity. Avšak aj napriek tomu, že text primárne oslovuje vysokoškolských študentov, svojou l'ahkost'ou a erudovanost'ou vie zaujat' aj širokú odbornú a vedeckú verejnost', ktorá sa interesuje o antické dedičstvo starovekých Grékov.

Učebnica je členená na viacero častí. Okrem predslovu a obligatórneho úvodu pozostáva vysokoškolská učebnica z dvoch hlavných kapitol: 1. Kynizmus ako

2 Recenzia vznikla ako súčast' riešenia grantu VEGA 1/0885/14 Fontes Cynicorum: pramene kynizmu a ich interpretácia. 
kultúrne hnutie, 2. Diogenés: etika bez morálky. Predslov zdôvodňuje vznik vysokoškolskej učebnice, jej ciel', štruktúru a metodiku práce s učebnicovým textom. V úvode autor poukazuje na výraznú historickú nezainteresovanost' o kynizmus. K obratu dochádza až v 70-tych rokoch 20. storočia, kedy sa kynizmus teší zvýšenému a systematicky narastajúcemu záujmu. 0 tom svedčí aj zoznam najvýznamnejších titulov, ktoré sa zaoberajú jeho interpretáciou (s. 7). Vzhl’adom na charakter práce je súčast’ou učebného textu aj Jazyková poznámka, Zoznam použitých skratiek, Latinské skratky antických autorov a diel. Vysoko prínosným je niekol'kostranový zoznam použitej literatúry, ktorý je bohatý na cudzojazyčnú literatúru rozmanitej proveniencie. Samotný charakter textu ako učebnicového podčiarkuje posledná čast' s názvom Orientačné témy seminárov, navrhnutá Líviou Flachbartovou. Každú tému, okrem stručne načrtnutých a možných problémov riešenia, sprevádza aj pramenná a interpretačná literatúra. Je potrebné spomenút', že značná čast' dochovaných správ, na ktoré sa autor odvoláva v rozsahu celého učebného textu, vznikla záslužnou a vytrvalou prekladatel'skou činnost'ou Andreja Kalaša.

Celkové členenie učebného textu je systematické a logicky nadväzujúce. Štýl je jasný, miestami vyžadujúci vyššiu pozornost’ čitatel'a, a to najmä pri uvádzaní gréckej terminológie, pri citovaní textov v originálnom gréckom znení, ktoré sú však zároveň doplnené o slovenské preklady. Pre študentov (a nielen pre nich) sa tak učebnica stáva výzvou zorientovat' sa, lepšie poznat' a porovnat' terminológiu, ktorá je pre kynizmus typická, odvolávajúc sa na autorov a zdroje referujúcich o kynikoch.

Učebnica sa snaží zodpovedat' základnú otázku, ktorú autor kladie v úvode a ktorá sa týka historického významu a hodnoty kynizmu. Bola to filozofická škola, akýsi „súbor vedenia“ (s. 10), majúci teoretický charakter, alebo len svojský životný štýl, „životná praxis“, činy a život sám ako prejav praktického uskutočňovania učenia filozofov? Autor rozvíja odpovede a polemiku, pričom sa opiera o hodnotenie kynizmu v staroveku podl'a antickej doxografie. Naopak, aby sa vyvaroval problémom, ktoré z uplatnenia moderných kritérií vyplývajú, odmieta posudzovat' kynizmus v rámci moderného výkladu. Ako dôvod uvádza odlišný spôsob chápania a vymedzenia filozofie $\mathrm{v}$ antike a v novoveku.

Autor tak v úvode stanovuje jasný ciel', ktorý má kurz a učebnica naplnit'. Ciel'om je zorientovat' sa v kynizme ako vo filozofickom hnutí, ktoré má v antickom myslení svoje relevantné a nezastupitel'né miesto. Pri napíňaní a realizácií tohto ciel'a však zároveň zdôrazňuje zohl'adnit' aspekt odlišnosti, rozdiely medzi antickou a modernou interpretáciou kynizmu. Stanovenému zámeru zodpovedá členenie textu do dvoch kapitol, častí. Prvá, ako jasne naznačuje jej názov (Kynizmus ako kultúrne hnutie), približuje kynizmus ako hnutie, a teda ako niečo odlišné tomu, čo v modernom jazyku označujeme filozofickou činnost'ou. V snahe o čo 
najadekvátnejšie zmapovanie kynizmu sa autor vyhýba moderným interpretáciám diferencie teoretického a praktického. Pretože na rozdiel od moderného myslenia je v antickom myslení teoretické filozofovanie nejakým spôsobom spojené s praktickým žitím.

Prvá čast' predstavuje čitatel'ovi hrubý náčrt vývoja antického kynizmu. Autor nechce zredukovat' kynizmus na kritiku konvenčnosti, na hnutie spojené s nástupom novej helenistickej epochy. Približuje kynizmus ovel'a širšie, „ako pohyb, ktorý sa uskutočňuje na viacerých časových osiach“ (s. 16). Odôvodnene obchádza jednoznačné, vel'akrát nepresné interpretácie a zameriava sa na raný grécky kynizmus, rímsky kynizmus a napokon problematizuje kynizmus ako školu. V tomto zmysle člení prvú kapitolu do troch podkapitol.

V prvej z nich (Raný grécky kynizmus a jeho vplyv na helenistické myslenia) opisuje kynizmus, pre ktorý je charakteristický krajný individualizmus, intelektuálna nezávislost', túžba po slobode, „sloboda reči“, kritika voči zotročujúcej konvenčnosti, inštitúciám, moci, autoritám a zákonom. Obraz kynického spôsobu života je obrazom sebestačného života, oslobodeného od všetkého, čo zotročuje jeho prirodzenost', čo mu bráni viest' blažený a št'astný život. Autor sa opiera o doxografické správy a hl'adá ideovú spojitost', tematickú zhodu medzi tým, „kto žije ako pes“ (s. 17), t. j. Diogenom zo Sinópy ako prvým kynikom - psom vo vlastnom zmysle slova - a Kratétom Thébskym, jeho družkou Hipparchiou a d'alšou generáciou kynikov (Menippos z Gadár, Bión z Borysthenu). Diogenovské väzby hl’adá aj s megarským (Stilpón z Megary), atomistickým (Anaxarchos z Abdér), skeptickým (Pyrrhón z Elidy) a stoickým (Zenón z Kitia, Aristón z Chios) myslením. Autor sa však nezaoberá len tým, čo spája kynizmus s jeho gréckymi prívržencami, ale aj tým, čo ich odkláňa od kynickej pozície (spor raného stoicizmu o indiferentných veciach a koncept oikeiósis). Záver tejto podkapitoly je už len menovitým oboznámením sa s vplyvmi kynických žánrov v grécko-rímskej literatúre a zároveň zdôraznením, že hoci sa nezachovali doxografické správy z 2. - 1. storočia pred n. l., to nevylučuje, že kynizmus nemal aj v tomto období svojich stúpencov.

Nadväzujúca druhá podkapitola Kynizmus v období rímskeho cisárstva menuje celú plejádu nástupcov raného kynizmu v rôznych mestách rímskeho cisárstva. Neboli to len osobnosti, jednotlivci, ale aj myšlienkové či sociálne skupiny. Ich množstvo postavilo autora pred otázku právoplatného nástupcu raných kynikov, ked’že rôznorodost' prívržencov zo sebou niesla selektívny prístup ku kynickému spôsobu života. Mapuje, čo ktorý neskorší prívrženec, kynik prakticky uplatňoval ako pôvodné, prípadne ako vcelku nové (napr. tzv. kolektívne praktiky, zmiešaný kynizmus). Rímsky kynizmus bol práve vd’aka novým prvkom značne populárny pre široké masy. Autor približuje kynizmus v spätosti so stoikmi (Epiktétos, Marcus Aurelius) a s literárnym hnutím „druhej sofistiky“ (Dión Chrysostom, Lúkianos, Maximos z Tyru). 
Kynizmus ako škola? je názov poslednej časti prvej kapitoly. Jeho opytovacia forma, vzhl’adom na predošlú škálu myslitel’ov, ktorí sa hlásili ku kynizmu, je opodstatnená. Autor takto postaveným názvom problematizuje status „kynickej školy“, a dokonca aj jeho doxograficky prezentovaného zakladatel'a Antisthena. Autor sa domnieva, že tradícia a správy, ktoré spájajú Antisthena so založením kynizmu, mali skôr účelový význam, slovami autora - mali len „vylepšit’ rodokmeň" stoikov prostredníctvom sokratovského pôvodu kynizmu (s. 42). Táto čast' práce analyzuje postavu Antisthena ako sokratovca, spochybňuje ho ako priameho Diogenovho učitel'a, ale aj ako legendu kynizmu. Aj ked' tomu nasvedčujú mnohé autorom využité bibliografické zdroje, neodmieta myšlienku, že by Antisthenes nebol duchovným učitel'om kynikov, vzorom filozofa, ktorý neteoretizuje, ale hl'adá cestu k dobrému žitiu. Text oboznamuje čitatel'a s tým, že kynizmus ako najvplyvnejší prúd sokratiky, ktorý rozvinul viaceré sokratovské motívy (s. 49), ovplyvnil predovšetkým rôzne literárne žánre. Autor zároveň poukazuje na prekážky pri štúdiu kynizmu, ktoré vyplývajú z dochovaných a sporných správ o kynikoch. Svojím pôvodom sú neskoršieho dáta, a teda z rímskeho obdobia, čo značne marí autorovu (ale nielen autorovu) snahu zachytit' ich skutočnú historickú hodnotu. Kynizmus so svojím vyhraneným individualizmom nemá charakter typicky filozofickej školy, čo autor spochybňuje aj v súvislosti s prepojením s Kynosargom, školou založenou Antisthenom. Záverom podkapitoly je priblíženie kynikov ako akéhosi „kultúrneho hnutia“ (s. 45) vo vzt'ahu k morálke, k prirodzenosti, k slobode a ideálu sebestačnosti.

Ani vdruhej časti, ktorá mapuje kynickú problematizáciu vzt’ahu etiky a morálky, autor nezaostáva vo svojom prístupe neposudzovat' podl'a novovekých kritérií a interpretácií. To, čo je v modernom myslení nepredstavitel'né, t. j. oddelenie etiky od morálky, je naopak v antickom obraze kynizmu predpokladom slobody. Autor hned' v úvodných slovách kapitoly uznáva Diogéna zo Sinópy za pomyselného zakladatel'a kynizmu (s. 53). Tento názor je v podstate výsledkom jeho interpretácií a kritických analýz doxografických správ a zdrojov v predchádzajúcich častiach práce. Vykresl'uje Diogena ako toho, kto nepotreboval učitel'ov a kto v zmysle idey sebestačnosti postavil zviera nad človeka. Prostredníctvom kynických spisovatel'ov približuje Diogena ako literárnu postavu a ako symbol kynického životného postoja. To spôsobilo zrodenie typicky kynického žánru (spúdogeloion), ktorý sa d’alej rozvíjal a ovplyvňoval satirickú literatúru. Autor sa opiera o mnohé doxografické správy, aby zachytil Diogenove životné príbehy ako ukážky kynického spôsobu života (Diogenes ako otrok a zajatec, ako falšovatel' obeživa, ako bojovník proti osudu, konvencii, za slobodu a prirodzenost', za dobrý život, Diogenes ako hlásatel' Sokrata a kritik Platóna). V texte autor nezabúda ani na otázku vzt'ahu kynizmu a sokratiky, ich vzájomnej spätosti, na problém úlohy výchovy, zdatnosti ako podmienky blaženého života. 
Predložený učebný text spíňa požiadavky kladené na takýto druh publikácie. Autor otvára priestor na d'alšiu diskusiu, či už medzi študentmi kurzu filozofie a etiky, ktorým je učebnica určená, alebo odborníkmi na antické dejiny a filozofiu. Dôkladne vyberá dostupné pramene $\mathrm{z}$ doxografickej tradície a iné zdroje, aby ich podrobil textovej analýze. Pre vytvorenie adekvátneho obrazu o kynizme sa zámerne vyhýba bežným učebnicovým výkladom a povrchným interpretáciám, aby úspešne vytvoril kohézny, logicky nadväzujúci, zmysluplný a obohacujúci text.

Marcela Maglione

\section{Literatúra}

SUVÁK, V. (2007): Sokratika: Štyri štúdie k sókratovskej tradícii myslenia. Prešov: FF PU.

Mgr. Marcela Maglione, PhD.

Katedra pedagogických štúdií

Fakulta humanitných vied

Žilinská univerzita v Žiline

Univerzitná 8215/1

01026 Žilina

Slovenská republika

marcela.maglione@gmail.com 